
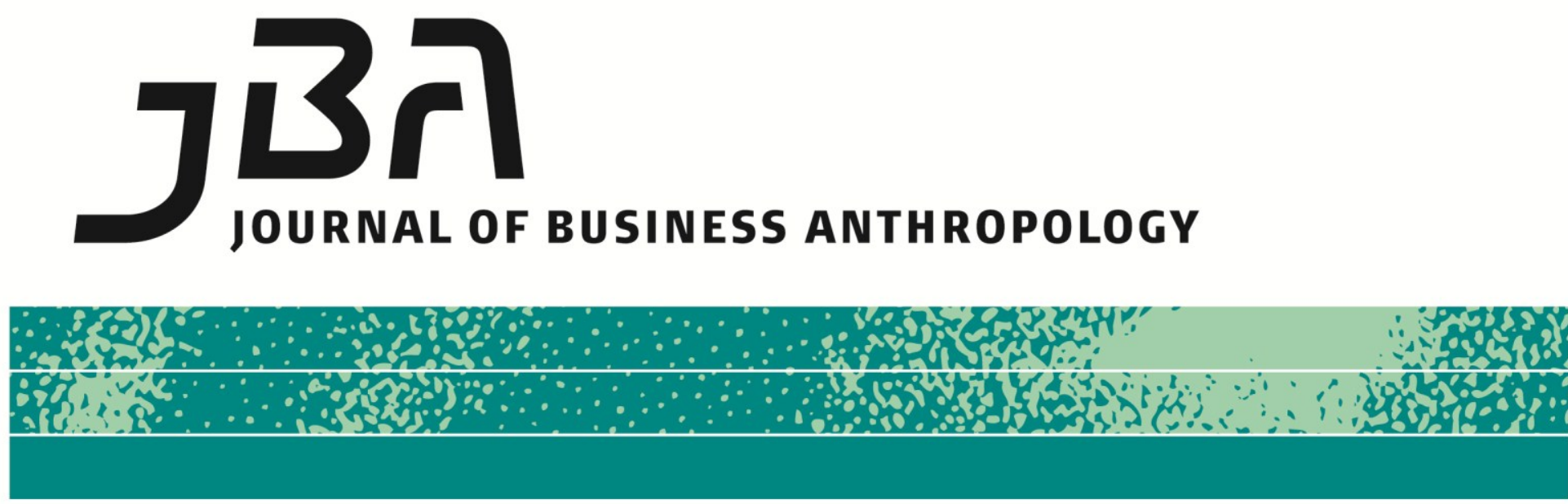

\title{
Writing Advertising: the Production of Relationships in Historical Review
}

Timothy de Waal Malefyt

\begin{abstract}
This article examines a range of writings on advertising. It shows that advertising has been written about as instrumental to an emerging capitalistic market, touted as a flamboyant lifestyle in autobiographical tales of charismatic advertising leaders, depicted as a coercive tool of manipulation for creating false desires in consumers, and analyzed for its complex social and political relations among its internal divisions and suppliers. I argue that the many ways advertising is written about reveal an ever-changing structural alignment within advertising itself, in what Pierre Bourdieu (1993) calls a field of strategic relations and possibles. In this, advertising, as well as the writing about advertising, is shown from a shifting 'production of relations' relative to economic, political, social and self-intended issues. The article concludes with possible future directions that writings on advertising will take.
\end{abstract}

Page 1 of 21

JBA 1 (2): 218-239 Autumn 2012

(C) The Author(s) 2012 ISSN 2245-4217

www.cbs.dk/jba

\section{Keywords}

Advertising, historical perspective, anthropology, consumption, strategic relations 


\section{Introduction}

What is advertising? What are its products and its effects on intended and unintended others? How do we look at the business of what it is and does, and why it exists? Various writers over the years have vetted these questions to celebrate, admire, vilify or puzzle over what advertising provides society in general, and consumers in particular. Advertising has been written about as instrumental to an emerging capitalistic market, touted as a flamboyant lifestyle in autobiographical tales of charismatic advertising leaders, depicted as a coercive tool of manipulation for creating false desires in consumers, and analyzed for its complex social and political relations among its internal divisions and suppliers. Because advertising is a creative industry operating in a constantly shifting political, economic and aesthetic milieu (Barthes 1972; Baudrillard 1994; Lash and Urry 1994) and because it produces nothing tangible, in and of itself, but rather links ideas, thoughts and images with lifestyles, values and modes of consumption, it evokes strong reactions in its written evaluations. Very few writers of advertising are indifferent to it.

I will argue that among the various perspectives written on the subject, advertising is shown to be in the business of producing relations. This builds on the idea suggested by Moeran (1996a, 2003, 2006), and Malefyt (forthcoming). In this article, I use this idea of producing relations to explore a range of historical writings on advertising. As a vehicle for consumption advertising produces relations between ideas and things, between various groups, institutions and individual people in its operation, and, as I will discuss here, between the ways writers of advertising discuss it, in relation to what they think its value is and for whom. In light of this focus, I will provide an overview of the historical writings on advertising as a form of shifting 'production of relations'. The many ways it is written about reveal an ever-changing structural alignment in advertising itself, in what Pierre Bourdieu would call a field of strategic relations and possibles (1993: 33-39).

According to Pierre Bourdieu, advertising exists in a relational field, occupying a position in a plane of possible position-taking strategies (1993: 33-34; see also Moeran [1996a, 2003, 2006] and Malefyt [forthcoming]). The specificity of advertising is defined by the fact that it produces no durable or tangible goods but rather ideas evaluated by others. Since, like a work of art, advertising is autonomous in its own right, it is most favorable to symbolic power. Advertising converts commodity objects and services into symbolic images and narratives that are valued and adapted to localized tastes. Its position, then, is always relative to other factors that shift in a constantly 
changing field of artistic, political, social and economic production. When Bourdieu speaks of a field of position-taking, it is within this system of relations, which are in struggles with other positions, that creates an ever shifting field of strategic possibles. The field of positiontaking possibles changes according to different economic, social, political and self-intended rules. In this way, as advertising is said to help produce culture (Kemper 2001, Miller 1997), culture can also be said to help produce advertising, in a relationship that is always in the making. Advertising is thus explored relationally in this article, through the various ways its writers, such as social critics, scholars, advertising men, historians and journalists, evaluate it relative to social, political, economic, or artistic perspectives on what they believe it should or shouldn't accomplish for society.

\section{Advertising as Social Mirror}

One approach that many writers on advertising have undertaken is to relate it to what is happening economically, politically and socially at a particular time and locale. Advertising becomes a lens through which to examine or reflect on changing social norms. The following critiques of advertising - some positive, others negative, and others historical in scope - have examined advertising and the rise of consumer culture in relation to social changes; advertising here becomes a way to applaud or condemn conditions such as economic growth, emerging prosperity, world politics, emergent gender roles, class struggles, or the overconsumption of goods.

One of the first detailed historical overviews of advertising came from Harvard Business professor, Ralph Hower (1939). This early work focused on advertising's influence in an emerging capitalistic society by tracing the beginnings of the advertising industry in the nineteenth and twentieth century. Hower exemplified this through an in-depth analysis of the Philadelphia-based advertising agency, N.W. Ayer and Son. Drawing on the agency's archival resources, this masterful work described the foundations of Ayer's client relations, agency functions as they developed, and the ways that advertising was employed to spread an awareness of goods in a burgeoning consumer market. Hower admired the growth of the advertising industry as he linked it to the rise of capitalism in the nineteenth and twentieth centuries.

Marshall McLuhan saw advertising differently, reflecting as it were, a new form of 'myth-making' in US society. In his publication of The Mechanical Bride (1967 [1951]), he examined a range of advertised material culture as a social mirror, from film posters, comic strips, magazine covers, newsprint and advertising, and showed how ads were intended to 'get inside' the collective public mind. In analyzing the content of media, deciphering what the subliminal messages are saying 
to people unconsciously, he postulated media's role as creating 'the folklore of industrial man'. Advertising was modern man's 'cave art'. His work, which detailed the persuasive techniques of advertising in forming a consumer culture, inspired further studies on advertising as a form of cultural critique.

Although an outsider to the industry, Martin Mayer's (1957) Madison Avenue U.S.A. provided an internal account of advertising from a journalist's perspective. This work brought controversy to the popularized image of advertising in America by describing the 'warfare' of new business and the infighting among media and between agencies, where men in advertising were skilled and had 'a natural gift for mass persuasion' or a 'remarkable ability to analyze and judge the meaning of personal existence' (1957: 12). Nevertheless, his work highlighted the important value of advertising in society by forging political opinion, galvanizing ambition, and influencing economic organization.

Other works that reflected advertising's relationship to changes in society were more apprehensive of an emergent political world order. Vance Packard's The Hidden Persuaders (1957) capitalized on rising public fears of coercive marketing practices and the use of subliminal messaging in advertising. ${ }^{1}$ Packard attempted to persuade readers that advertisers used various covert psychological methods, such as subliminal advertising, to tap into consumers' unconscious desires and thus manipulate the public into buying the increasingly mass-produced products they were selling. Advertisers were thought to use psychological techniques to probe consumers' minds and motivations in order to control consumer behavior. Through his analysis of commercial products, political campaigns and television programs of the 1950s, Packard suggested that insidious manipulation practices would come to dominate today's marketing practices. This was the first book to expose a so-called hidden world of persuasive methods in advertising. In revealing a fear of marketing surveillance on consumer society, it also reflected, in part, a growing public fear of an emerging cold war.

Rachel Bowlby (2001), comments on this era of advertising as also reflecting changing gender roles vis a vis consumption. At the time Packard's book was written, consumers, and especially women, were largely viewed as passive recipients of advertising. The compelling idea for advertisers was to introduce 'impulsive' influences in the marketplace at points of purchase, such as in-store ads, promotions and purchases in unexpected locations, thus encouraging consumers to 'deviate' from their normal shopping routine (2001: 237). Notably, the passive/receptive view of shoppers described by Bowlby corresponded to societal views of women at the time as being fulfilled by their

\footnotetext{
1 This negative view towards advertising was earlier asserted in E. S. Turner's book, The Shocking History of Advertising (1953).
} 
subservient role in housekeeping. Advertising was thus regarded as a 'brainwashing' influence on the 'mindless' housewife of the 1950s, making her open to suggestions she might not otherwise take (Bowlby 2001: 200). Packard's book, in this regard, also subtly reflected a view of women shoppers as particularly vulnerable to the techniques of Madison Avenue.

Other critiques of advertising that reflected a view of social change described its influence on class issues in terms of struggles over power and dominance. Embedded in these commentaries was a notion that advertising instilled a sense of order and conformity of tastes, where consumer differences were masked by messages that projected more or less similar 'homogenized' tastes. The historian Daniel Boorstin (1965) wrote that early American advertising was a 'declaration of equality', one that catered to a vague and indiscriminant mass market, which 'thrives on tastes that are completely average' (1965: 88-89). William O'Barr (1994) more critically examined twentieth century advertising on how it influenced social order. Early advertising images of American society, he claimed, were conspicuously absent of ethnic, gender or socio-economic differences, and reflected instead the selfrestrained dominant order of white protestant males. O'Barr maintained that advertising 'has tended throughout the twentieth century to treat the American public as a colorless, English-speaking mass audience of rather uniform tastes, preferences and sensibilities' (1994: ix).

Advertising is thought of here as an insidious form of social control over diverse socio-economic differences, which conceals underlying tensions in society.

Roland Marchand's Advertising the American Dream (1985) offered a more positive historical perspective on advertising's relation to issues of socio-ethnic diversity and social integration. His work provided a detailed and thoughtful analysis of trends in the style of American advertisements from 1920 to 1940 . He showed that advertising images and texts offered new immigrants to America a set of norms, behaviors and styles that were appropriate for learning how to adapt and fit in socially. Advertising was an effective tool for social integration for Marchand, because it portrayed living pictures, or what he called 'social tableaus', much like the genre of theater entertainment that 'brought to life' familiar scenes and provided people images of themselves as they aspired to be.

Still other scholars have taken this 'social mirror' approach to show that advertising can reflect an archival record or 'family album of society'. Russell Belk and Richard Pollay showed that advertising, over the course of the twentieth century, depicted cultural images for desirable manners, styles, entertainments, and even lifestyles of the 'good life' (Belk and Pollay 1985).

A notable critique of advertising, Michael Schudson's 
Advertising: The Uneasy Persuasion (1984), also maintained that advertising was a necessary force in society, since it promoted consumption as a way of life. But he offered a different analysis, proclaiming 'its dubious impact on American society'. He asserted that advertising was far less effective in influencing tastes and consumption desires than many critics of the industry had claimed. He postulated, rather, that mass advertising regularly 'miscommunicates' by addressing unintended audiences, or communicates to an audience different from the actual intended audience. He maintained that population, income, and other environmental variables were more decisive in driving product sales than advertising. Advertising worked more by 'repetition' than by 'the subtle transmission of values' (1984: 5). This work by a sociologist was one of the first scholarly studies to confront advertising, and minimize its persuasive influence on social change.

James Twitchell, also asserted that advertising was necessary for the development of modern social life, claiming that 'the culture we live in is carried on the back of advertising' (1996a: 67). He coined the phrase 'AdCult' to describe the space created in American culture for advertising to convey messages about brands that people want to learn about and consume (1996a, 1996b). Commercial advertising, he posited, was essential to convey the differences in things that are often similar. AdCult expressed a culture of what people want in things (goods), only recombined them in new ways through existing and new medias.

Twitchell, like Schudson, however, criticized the ad industry and the concomitant over-consumption of goods by asserting that advertising only functions in times of abundance, among a surplus of goods. When goods become interchangeable through sharing competitive features and abundant in surplus quantities, and when consumers have extra time and money to spend, then AdCult remains the dominant meaningmaking system in modern life (1996a: 77). In essence, he suggested that advertising exists to help create for us a sense of difference in an oversaturated marketplace of consumer goods.

These works, by and large, examined advertising as a means to explain the vast changes occurring in society and consumer culture. Advertising was a force that borrowed images, narratives and values from society, and then circulated them back in society to shape people's desires for material culture. Advertising thus offered people a way to adapt and fit in, or aspire for something else. From this perspective, advertising was therefore necessary for facilitating social adaptation and the development of norms, customs, styles and desires associated with different lifestyles in society. While advertising itself may be critiqued positively or negatively, it was valued in these writings as an explanatory tool for reflecting and analyzing what transpired in social life. 


\section{Advertising the good life: Adventure, fun, and celebrity status}

Advertising is also written about in relation to the glamorous lifestyles of its powerful and well-known elite. Much of the popular, stylish image of advertising came from the stories of its standout personalities and notable leaders. These works were written as autobiographies to celebrate charismatic figureheads, such as Bill Bernbach, Norman B. Rossiter, David Ogilvy and Rosser Reeves. These written accounts characterized the field of advertising through artistic, innovative, and often entrepreneurial personas that were called to face the rising commercial industry in American culture.

Advertising executive, Rosser Reeves, wrote Reality in Advertising (1960), in which he set out a list of clever and witty aphorisms that supposedly pertained to his work in advertising and, of course by association, to life in general. For example, while the Chinese may have coined the phrase, 'One picture is worth a thousand words', he re-wrote it as a clever advertising aphorism stating, 'One wrong picture can steal a thousand words' (Reeves 1960: 108). Rosser Reeves notably claimed that the 'art of advertising' was getting into people's heads through the unique selling proposition, which expressed a particular reason one product bought should be better than its competitors. His memorable slogans - such as M\&M's candies, 'Melt in your mouth, not in your hand' - are recalled to this day.

Another work written posthumously to venerate a major figurehead in advertising was A Tribute to Leo Burnett (1971). This work consisted of various collected memoranda, speeches and aphorisms, made famous by advertising executive Leo Burnett during his lifetime. The public's interest in advertising also encouraged the re-publication of a handful of other titles by lesser-known members of the advertising industry. Other autobiographies were Claude C. Hopkins's Scientific Advertising, which detailed the 'scientific' use of direct response techniques and testing advertising campaign headlines in small controlled tests to verify a campaign, before spending large sums of money, and in My Life in Advertising (republished in 1966, first published in 1923 and 1927 respectively). Along these lines, James W. Young published The Diary of an Ad Man (1946) and How to Become an Advertising Man (1963). Other works that followed in this genre were less self-promotional and sought to amuse as well as instruct: Peter Mayle's Up the Agency (1990), for example, or Randall Rothenberg's Where the Suckers Moon (1994).

Most famously, David Ogilvy, wrote his autobiographical Confessions of an Advertising Man (1963). Ogilvy admitted that he originally wrote this book to attract new clients to his agency, prepare the economic market for a public offering of Ogilvy's shares, and to 
advertise himself in the business world. The widespread popularity of his book succeeded on all counts. He began his story of how Ogilvy \& Mather came into existence by discussing the personal lessons he learned from his days working as an elite chef in Paris, before going on to describe his personal experiences with running an advertising agency as he set forth his principles on which to base success. Ogilvy evinced a casual, largely anecdotal, and occasionally pompous style to his writing. He was himself a copywriter and clearly expressed admiration for those who write copy for a living. His later work, Ogilvy on Advertising (1985), is considered more serious and instructional on how to develop advertising.

These works were generally written for the public's diversion, exploiting a fast paced, glamorous image of advertising in breezy prose. This genre of popular self-promoting narratives blurred the lines between artistic figurehead and exciting lifestyle, and helped publicize the advertising profession as well as self-promote particular authors and their agencies. For instance, Ogilvy describes his hard work, but also his frequent vacations, foreign travel, and meetings with famous names. Examining these works as a whole, the value of these advertising tales resides not in their ability to sell goods or services, but rather as Bourdieu (1993) describes of artists, for developing value in name recognition from others. These works, indeed, helped launch a 'name economy' in advertising, which thrives on celebrity status, crossing domains, and restricted production (Moeran 2003). Esteem given to individuals by the popularity of these tales formed the symbolic capital in accumulated prestige, celebrity and honor, bestowed on them through recognition. Their books, in part, romanticized the advertising profession and way of life, and are now idealized in popular TV programs like Mad Men.

\section{Decoding advertising: the circulation of signs and symbols}

In 1970s through the 1990s another mode of describing advertising's relation to society, the economy, and consumers in particular, came from scholars who critiqued advertising not for its internal processes or perspectives, but rather for its products: advertisements. These works largely applied textual analyses and semiotic approaches to 'decoding' the circulation of advertised messages in society. Advertisements were more or less 'read' as signs and symbols, and analyzed as forms of social discourse (Baudrillard 1994; Lash and Urry 1994; Goldman and Papson 1996; Perry 1998). Critics were concerned less with how ads were made or who made them, and more concerned with the effects of advertisements on society and their underlying social, racial and gendered messages. 
Writer and art critic John Berger first brought a semiotic awareness to advertisements when he compared popular advertising images with representations in art. His book, Ways of Seeing (1972), accompanied a popular BBC Television series, but offered a more critical view of advertising. Berger was particularly interested in the process of 'deconstructing' the apparatus of art criticism, laying bare the mechanics, manipulations and limitations of images that were circulated in society, often by means of advertising. His influential book launched a number of other structuralist analyses of advertising that explored it from a largely linguistic or semiotic framework (Varda Langholz Leymore's Hidden Myth [1975], see also Vestergaard and Schroder 1985; Tanaka 1994).

Along these lines, Judith Williamson's Decoding Advertisements (1978) also examined the circulation of advertising messages, and offered a textual analysis for decoding the structures of the genre. She was concerned with exposing the underlying ideological constructions associated with particular advertising techniques. If the overt economic function of advertisements was to appeal to us and make us buy things, then its ideological function was to collectively involve us as 'individuals' in perpetuating these ideas, which support and validate the economic basis of our society. Williams perceived advertising as the 'official art' of a modern capitalist society, a semiotic system for creating and circulating meaning in society.

Another work that provided a semiotic take on the social value of advertising is Sut Jhally's (1987), The Codes of Advertising. Jhally discussed the widespread influence of advertising and held that its social significance greatly exceeded its economic influence. He described it as a vital 'mediator' between culture and the economy, as well as between people and products. Jhally and other authors (Leiss, Kline and Jhally 1986) further declared advertising as a 'privileged discourse' for the circulation of messages and social cues, which informed types of interactions between persons and objects.

A notable stand-out among these critiques was Erving Goffman's Gender Advertisements (1979). His work thoughtfully demonstrated how the visual images of men and women expressing 'natural behavior' in advertisements actually revealed and reinforced ritualized gender displays. The subtleties expressed in ads, such as depicting differences in relative size and position between men and women posed next to one another, or how the role of the female caress in images depicted a subjugated social role for women through touch, or how women in ads were often placed in subordinate postural positions relative to men, were themselves 'gender displays', reinforcing and 'iconically reflect[ing] the fundamental features of the social structure' (1979: 8).

There are a number of other social scholars and anthropologists who have examined advertising through mainly semiotic or linguistic 
approaches (e.g. Moeran 1996b; Beebe 2004; Lury 2004; Arvidsson 2006). Anthropologist John Sherry examines advertising as a cultural system, which he believes offers people a vehicle for understanding the structures of reality within their own culture. Sherry claims advertising contributes to organizing experiences of people through the shaping and reflecting of reality - a way of presenting, apprehending and knowing the world, in much the same way that religion, science, common sense, art, ideology or play represent ways of knowing (1987: 442). John McCreery (1995) postulates that advertising works, not as much like religion with believers, but more like magic in how it manipulates through persuasive tools. Ads as part of a cultural system, then, are vehicles - magically or religiously directed- to 'transfer meaning', as McCracken puts it $(1986,1988)$, to bring a consumer good and representations of the culturally constituted world together within the frame of an advertisement. Ads analyzed as conduits through which meaning flows from culture to the world of goods, shows a system of continual making and re-making of relationships, with new goods continuously giving up and replacing old meanings with new ones. Consumers, then, are given 'freedom to choose' and participate in a culture of consumption (Beeman 1986). Advertising from these semiotic views serves as a 'lexicon' for circulating cultural meaning. This exemplifies what Bourdieu would call the field of production, where the consumer and producer equally participate in cultural production by completing the consumption process in a series of mutual exchanges.

\section{Internal accounts of advertising}

After all these different approaches to the study of advertising (in business, history, autobiographies, cultural studies, and semiotics) described in the previous section, I turn to the more recent anthropological approaches, since it is these that have really opened up the 'black box' of the advertising industry (as opposed to analyzing its products or effects on society).

Missing from these other monologues discussed above is the sense of 'being there', gathering how people in the advertising business actually go about their daily business and relate to each other to produce advertising. What happens in the daily life of various members in an agency? Who are the individuals that conduct research, gather in meetings, pitch an account, develop advertisements, negotiate media, and distribute them through networks? What are the myriad relations among constituents, and between producers and suppliers supporting these efforts? As Howard Becker (1982) writes, any form of art involves implicit and explicit contributions from relations among multiple constituents along the way; all art involves the cooperation of others (1982: 7). Missing from these other accounts are the details of daily life 
of advertising from within. 'Ethnographic writings can and do inform human conduct and judgment in innumerable ways by pointing to the choices and restrictions that reside at the very heart of social life' (Van Maanen 1988: 1). The following anthropologists write first hand to the social life and human relations in advertising, and present to the reader the choices, conflicts and resolutions that people in advertising live on a daily basis. Many of these ethnographic works are international in scope, analyzing advertising's influence on local culture from global influences. They importantly show advertising's effects cross-culturally.

A significant early work on advertising by an anthropologist is Daniel Miller's study of consumption in Trinidad. In Capitalism: An Ethnographic Approach (1997), Miller examines the regional Trinidad context as the setting for the production of commodities as 'complex symbolic formulations' (1997: 4) in which marketing, branding and advertising play a major role. This work focuses mainly on food and beverage commodity production in Trinidad society, and not particularly on the role of advertising. What he does write of advertising, though, is descriptively penetrating of life between ad agencies. He details the intense rivalry among local advertising agencies, not so much for reaching consumers as among one another, for clients. He describes an atmosphere of animosity, where agencies are 'constantly looking for ways to poach clients from each other' (1997: 160). This tension incites a 'paranoia of competition' over clients among advertisers, keeping agencies sharply peeled to marketing tactics of pricing, promotions, and strategic moves from rivals (1997: 166). Miller refutes many of the earlier critiques on advertising that give too much sway to advertised images in the manipulation of its public. His work reveals, instead, how fear of other agencies and their products show an industry 'more reactive than proactive' (1997: 241- 242). By focusing on the ambivalence of whether an advert sells goods, whether a public is influenced by images, and concern for acceptance of advertising, he places a greater degree of agency in the hands of consumers than previously granted in studies of advertising.

Marianne Elisabeth Lien also produces an anthropologist's account of the marketing and advertising of food, in this case for Norway. In her book, Marketing and Modernity: An Ethnography of Marketing Practice (1997), Lien queries how the rising popularity of ready-made meals can be marketed and promoted to appear authentic, folksy and appealing in Norway. Her study of the Bon Appétit brand provides fertile ground to demonstrate how a convenience food could be promoted as a symbol of modernity to a growing affluent Norwegian society by achieving a balance between foreign and domestic culinary traditions. In another illuminating book chapter (Lien 2003), Lien discusses the use of advertising to create a 'folk pizza' in Norway. Pizza may be perceived as a foreign dish, originating in Italy and heavily 
marketed in America, but through identification with a localized Norwegian consumer target group, pizza becomes domesticated and recontextualized with Norwegian cultural values.

Anthropologist Steven Kemper's thoughtful monograph on the Sri Lankan advertising industry, Buying and Believing (2001), investigates how advertising in the cities of Nairobi, Caracas, Kuala Lumpur and Colombo produces new forms of culture in Sri Lankan society. His work considers the relationship that advertising fosters between Sri Lanka as a society, an economy and a locality, and the rest of the world. Advertising offers a powerful modernist integration between Sri Lankan identity, a 'New Age' Buddhist religion and ideas about ecological concern, economic restraint and personal balance. In this, the advertising industry introduces Sri Lankan consumers to new imaginings and practices such as urban life, prosperity, and modernity, typically associated with the West.

William Mazzarella's Shoveling Smoke (2003a; see also 2003b), also examines the process of globalizing consumerism from the view of the advertising industry in Bombay, India. He shows that advertising in India plays a critical role in mediating between the local and the global, between culture and capital. After a brief stint in a Bombay ad agency, he claims, advertising is critical to the modernization and development of Indian society, precisely at a time when the economy was transforming and opening its consumer markets to foreign brands. His work shows how brands are given a particular local (namely Indian) identity in reshaping notions of modernity and identity in a changing globalizing society. He theorizes advertising as a particular kind of cultural production in the public circulation of images. Through advertising, the commodification of culture itself is transformed into a new conception of progress in India.

Nevertheless, the first true in depth 'insider' view to advertising comes from an anthropologist who conducted extended fieldwork within a Japanese advertising agency. Brian Moeran's A Japanese Advertising agency (1996a) still stands as one of the only ethnographies to examine the interrelations across functions within an ad agency and its suppliers. In 1990, Moeran spent twelve months conducting participant-observation fieldwork in a large advertising agency in Tokyo and his work provides a detailed ethnographic account of how people in the advertising industry actually conduct their day-to-day business. It describes an agency's major divisions, and the people involved, from account services, marketing, creative development, and media buying. It also takes the reader through an actual agency pitch, showing how campaigns are negotiated, and how the industry as a whole is structured into competing institutions of advertising companies, agencies and media organizations. This pioneering work was later supplemented by a second book on advertising, Ethnography at Work (Moeran 2006), 
which shows how a single case study of preparations for an advertising campaign could then be theorized into multiple but complementary ways.

Following this work, Timothy Malefyt and Brian Moeran bring a number of related case studies together in a single edited volume, Advertising Cultures (2003). This volume is novel in describing agency life from various cross-cultural perspectives, and particularly focuses on comparing and contrasting how anthropologists working in diverse cultural areas as Sri Lanka, the US, Norway, India, Trinidad and Japan have considered and written about the advertising industries and marketing methods encountered there. It explores how ethnography, a staple of academic anthropologists, is practiced and theorized in advertising and marketing industries, and compares this with the academic discipline. We learn about the Japanese imagining the other in a new business pitch (Moeran), the persuasive measures and metaphors used in client-agency workshops (Malefyt), advertising in the garment industry (Olsen), authentic constructions of convenience foods (Lien), advertising, production and consumption in Trinidad (Miller), reflections on fieldwork in the Bombay advertising world (Mazzarella), how psychological models predominate in advertising and marketing research, which anthropologists must constantly deal with (Sunderland and Denny; see also Sunderland and Denny 2007).

The most recent work by Timothy Malefyt and Robert Morais, Advertising and Anthropology: Ethnographic Practice and Cultural Perspectives (2012), provides an internal view of advertising from two anthropologists who have spent extended time employed in advertising agencies. Malefyt and Morais have been employed full-time in advertising agencies for over a combined forty years. Their work contains unusual insider perspectives into the workings of advertising agencies, from how to win an account to how advertisers direct messages to consumers' emotions, to ideas on where and how creativity is generated by creative talent, which compares to the process of doing ethnography for anthropologists. Their work also reflects candidly and critically on the ethical issues of employment within an advertising agency and the daily responsibilities anthropologists face. Morais has also written on the meeting in advertising (2007), where he discusses the ways participants from a client and the advertising agency reach agreements for campaigns by communicating explicit and implicit rules. Such meetings take place regularly and reveal only what an insider, such as Morais, could gather from close proximity. Malefyt (2009) has also written about the widespread use of ethnography in marketing research and consumer studies. This work details the way ethnography has become branded, often with technological tools and methods, to differentiate from competitors, but diminishing the influence of the ethnographer him/herself. Malefyt, along with an anthropological 
colleague and consultant, Maryann McCabe, has also written on automobile advertising, and the ways successful and unsuccessful campaigns avail themselves to cultural material or failed to do so (McCabe and Malefyt 2010).

Other scholars have written about the 'inside workings' of ad agencies, and have cast light on little known workings of creativity, such as the ways advertising copywriters develop insights for the consumers they write for (Kover 1995), or work more assiduously within a set of fixed guidelines or restrictions (Moeran 2006, 2009). We learn from Arthur Kover that copywriters do not adhere to explicit theories of communication, but often implicitly articulate a common 'internal dialogue' with an imaginary consumer, testing their ideas against an imagined voice (Kover 1995). In another thoughtful article, Arthur Kover and Chris Hackley (2007) explore the stereotypes of advertising creatives' personalities, such as being a genius or maverick. They show that agency life is often a source of conflict and insecurity for creatives, yet also a site of potential fulfillment for them. An advertising creative's sense of identity is constructed from these opposing images, which the authors suggest could be better managed for positive creative outcomes.

Other studies, not directly about advertising but related to the industry, are being made by anthropologists who study corporations, brand identity, and other advertising related topics. Melissa Cefkin has edited Ethnography and the Corporate Encounter: Reflections on Research in and of Corporations (2009); Marietta Baba has written an overview of business and industrial anthropology (2006); Elizabeth Briody and colleagues have detailed the workings of corporate culture within the automobile industry (2010). Anthropologists Rita Denny and Patti Sunderland run an ethnographic consulting firm that often gains employment from work with advertising agencies. Their insightful book, Doing Anthropology in Consumer Research (2007), describes the issues for anthropologists working in the field of consumer research, which is otherwise dominated by psychological based theories and practices. Other recent studies of ad agency life with international scope are being conducted by younger anthropologists, such as Kimberly Couvson's (2009) investigation of a Chinese advertising agency in Beijing. This direction is heartening, since vast changes occurring in media and the advertising world call for more anthropologists to investigate new forms of relationships that advertising makes with its internal constituencies, external audiences, processes, and products.

\section{Writing on advertising and future directions}

The range of these writings on advertising, and the diversity of their evaluations relative to other subjects, demonstrates that advertising and the writing about advertising exist in a field of shifting relations. In these 
writings, advertising is subject to varying conditions that shape and alter its meaning according to how it is perceived, what it is compared to, and ultimately, to how it is evaluated. As Bourdieu notes, symbolic goods, such as advertising, 'are a two-faced reality, a commodity and a symbolic object. Their specifically cultural value and their commercial value remain relatively independent, although the economic sanction may come to reinforce their cultural concecration' (1993: 113). In what seems like a paradox, advertising - like many other creative industries (Caves 2000) - straddles the realm of style, aesthetics and art, as well as hardcore commerce. The emergence of these writers' particular approach to advertising and the shape of their distinctive narrative relate to a category of symbolic value - whether in terms of art, style, commerce, or lifestyle - and to other social, economic, political or personal issues. In some cases, we learn about advertising relative to autobiographical details and career lifestyles; in other cases, we see advertising used as a tool to admire or criticize consumption processes and social change; and in internal cases, we note from the writer that the advertising industry itself creates ways of relating among individuals or between one group and another.

Moreover, the relationship these writers make with the subject of advertising is often relative to their own work and to others who write on advertising, as well as relative to the field as a whole. Each position taken by a writer on the subject, according to Bourdieu, implies defining his or her position as divergent and contrastive to other positions (1993: 131). This perhaps explains the wide-ranging descriptions of advertising - condemning it, or supporting it, against other views. This follows from the paradoxical nature of advertising itself, both combining art and commerce, and yet distinguishing one from the other according to the position taken. The breadth of writings on advertising, therefore, is shown to range in perspective and evaluation, either defending or attacking one position from others, but always relating to a new subject or new theory by which to establish one's own position.

This may lead us to question what future writings on advertising will address, and how writers might develop, contradict, or reinterpret past and present writings on the subject. Indeed, advertising as a moving subject itself, has further morphed into new forms of relationships and social interaction. With the advent of the Internet, online blogs, Twitter, Facebook and mobile apps, information about products and brands circulates in record time, and consumers who purchase products and brands have greater awareness to brand behavior and social issues. Consequently consumers possess greater control to turn off or tune into advertised brand messages they may or may not like. 
An instance of this change is witnessed in the rise of digital commerce. With the arrival of the digital age the post-purchase cycle of consumption has become far more valuable today for advertisers. What consumers feel and discuss about a brand with their friends and colleagues after buying something is much more likely to affect a brand, than persuasive advertising alone, writes David Edelman, a McKinsey consultant writing in the Harvard Business Review. Edelman notes, for instance, that more than 60 per cent of consumers of facial skin care products conduct online research about the products they buy, and discuss with others their feelings after they purchase them (Edelman 2010: 67). This means that after purchase, consumers enter into an extended relationship period with a brand and are more likely to share their thoughts and feelings about a brand and advertised messages with others, online and off.

Advertising thus has entered a new phase where it seeks to pique the interest of buyers, so that they pursue additional ways to invest in a brand or product, develop lasting ties of loyalty and perhaps advocate for others to do the same. New writings on advertising will look to understand these new processes of post-purchase consumption and the ensuing community of dialogues that develop. While some experts in advertising call this the beginning of 'the relationship era' (Levy and Garfield 2012), the notion that humans develop loyalties to things and discuss them in communities is not new to scholarly investigation (Douglas and Isherwood 1979; Csikszentmihalyi and Rocheberg-Halton 1981; Miller 1997). Rather, for anthropologists studying and writing about the future of advertising, issues of fragmented media, multiple channels of involvement, and members of communities asserting loyalty to certain brands, means that there are additional fertile grounds for exploring the myriad ways in which culture becomes manifest in consumption, and the ways advertising attempts to develops relationships with them.

Writing on this new world of advertising will create the possibility for additional relations against which to position one's view of advertising. For anthropologists, these new realities of the marketplace offer novel ways to write about adaptation and change among producers and consumers of advertising. The new ways to write about advertising in these new modes of position-taking, which constitute the cultural field of production, will bring about their own particular set of problems and structures of resolution, each with various new themes and procedures, aesthetic concerns and issues about commerce and consumption. They will further show that advertising is in the business of producing relations vis a vis culture, as culture will show to produce new relations with advertising and new ways that it can be written about. 


\section{References}

Arvidsson, Adam 2006 Brands: Meaning and Value in Media Culture. London: Routledge.

Baba, Marietta 2006 'Anthropology and Business', in H. J. Birx (Ed.) Encyclopedia of Anthropology, Thousand Oaks, CA: Sage Publications.

Barthes, Roland 1972 Mythologies. London: Paladin.

Baudrillard, Jean 1994 Simulacra and Simulation. Ann Arbor: University of Michigan Press.

Becker, Howard 1982 Art Worlds. Berkeley: University of California Press.

Beebe, Barton 2004 'The Semiotic Analysis of Trademark Law.' UCLA Law Rev. 51 (3): 621-704.

Beeman, William 0. 1986 'Freedom to Choose: Symbols and Values in American Advertising.' In H. Varenne (ed.) Symbolizing America, pp. 5265. Lincoln: University of Nebraska Press.

Belk, Russell W. and Pollay, Richard W. 1985 'Images of Ourselves: The Good life in Twentieth Century Advertising.' Journal of Consumer Research 11 (4): 887-97.

Berger, John 1972 Ways of Seeing. London: British Broadcasting Corporation.

Boorstin, Daniel J. 1965 The Americans: The National Experience. New York: Random House.

Bourdieu, Pierre 1993 The Field of Cultural Production, New York: Columbia University Press.

Bowlby, R. 2001 Carried Away: The Invention of Modern Shopping. New York: Columbia University Press.

Briody, Elizabeth, Trotter, Robert and Meerwarth, Tracy 2010 Transforming Culture: Creating and Sustaining a Better Manufacturing Organization. New York: Palgrave Macmillan.

Burnett, Leo 1971 A Tribute to Leo Burnett: Through a selection of the inspiring words that he wrote or spoke. Chicago: Leo Burnett Co.

Caves, Richard 2000 Creative Industries: contracts between Art and Commerce. Cambridge, MA: Harvard University Press.

Cefkin, Melissa (Ed.) 2009 Ethnography and the Corporate Encounter: Reflections on Research in and of Corporations. New York: Berghahn Books. 
Couvson, Kimberly 2009 'China and the 'Creative' Idiom: A Study of an Advertising Agency in Beijing.' Unpublished dissertation, Cornell University.

Csikszentmihalyi, Mihalyi and Rocheberg-Halton, Edward 1981 The Meaning of Things: Domestic Symbols and the Self, New York: Cambridge University Press.

Douglas, Mary and Isherwood, Baron 1979 The World of Goods: Towards an Anthropology of Consumption, London: Routledge.

Edleman, David 2010 'Branding in the Digital Age: You're Spending Your Money in all the Wrong Places.' Harvard Business Review, December, 6269.

Goffman, Erving 1979 Gender Advertisements. New York: Macmillan.

Goldman, Robert, and Papson, Stephen 1996 Sign Wars: The Cluttered Landscape of Advertising. New York: Guilford Press.

Hackley, Chris and Kover, Arthur 2007 'The Trouble with Creatives: Negotiating Creative Identity in Advertising Agencies.' International Journal of Advertising 26 (1): 63-78.

Hopkins, Claude C. 1966 My Life in Advertising and Scientific Advertising. New York: McGraw-Hill.

Hower, Ralph 1939 The History of an Advertising Agency: N.W. Ayer \& Son at work 1869-1939. Cambridge: Harvard University Press.

Jhally, Sut 1987 The Codes of Advertising. London: Frances Pinter.

Jordan, Ann T. 2003 Business Anthropology. Prospect Heights: Waveland Press.

Kemper, Stephen 2001 Buying is Believing: Sri Lankan Advertising and Consumers in a Transnational World. Chicago: University of Chicago Press.

Kemper, Stephen 2003 'How Advertising Makes its Object.' in T. de Waal Malefyt and B. Moeran (eds), Advertising Cultures, pp. 35-54. Oxford: Berg.

Kover, Arthur 1995 'Copywriters' implicit theories of communication: an exploration.' Journal of Consumer Research 21 (4): 596-611.

Lash, Scott and Urry, John 1994 Economies of Signs and Space. London: Sage.

Leiss, W. Klein, Stephen and Jhally, Sut 1986 Social Communication in Advertising: Persons, Products and Images of Well-Being. New York: Methuen.

Levy, Doug and Garfield, Robert 2012 'Ignore the human element of marketing at your own peril: forget product positioning, this is the dawn of the relationship era.' Advertising Age, January 01. 
Lien, Marianne E. 1997 Marketing and Modernity: An Ethnography of Marketing Practice. Oxford: Berg.

Lien, Marianne E. 2003 'Fame and the Ordinary: 'Authentic' Constructions of Convenience Foods.' in T. de Waal Malefyt and B. Moeran (Eds.), Advertising Cultures, pp. 169-186. Oxford: Berg.

Lury, Celia 2004 Brands: The Logos of the Global Economy. London: Routledge.

Malefyt, Timothy de Waal 2009 'Understanding the Rise of Consumer Ethnography: Branding Techno-methodologies in the New Economy.' American Anthropologist, 111 (2): 201-210.

Malefyt, Timothy de Waal (forthcoming) 'Celebrity Status, Names, and Ideas in the Advertising Award System.' in B. Moeran and B. Christensen's (Eds.) Exploring Creativity, Cambridge: Cambridge University Press.

Malefyt, Timothy de Waal and Moeran, Brian (Eds.) 2003 Advertising Cultures, Oxford: Berg.

Malefyt, Timothy de Waal and Morais, Robert J. 2012 Advertising and Anthropology: Ethnographic Practice and Cultural Perspectives. Oxford: Berg.

Manovich, Lev 2001 The Language of New Media. Cambridge, MA: MIT Press.

Mayer, Martin 1957 Madison Avenue USA. New York: Pocket Books.

Mayle, Peter 1990 Up the Agency: the Funny Business of Advertising. New York: St. Martin's Press.

Mazzarella, William 2003a Shoveling Smoke: Advertising and Globalization in Contemporary India. Durham: Duke University Press.

Mazzarella, William 2003b 'Critical Publicity/Public Criticism: Reflections on Fieldwork in the Bombay Ad World.' In T. de Waal Malefyt and B. Moeran (eds.) Advertising Cultures, pp. 55-74. Oxford: Berg publishers.

McCabe, Maryann and Malefyt, Timothy de Waal 2010 'Brands, Interactivity, and Contested Fields: Exploring Production and Consumption in Cadillac and Infiniti Automobile Advertising Campaigns.' Human Organization 69 (3): 252-262.

McCracken, Grant 1986 'Culture and Consumption: A Theoretical Account of the Structure and Movement of the Cultural Meaning of Consumer Goods.' Journal of Consumer Research 13 (June), 71-84.

McCracken, Grant 1988 Culture and Consumption: New Approaches to the Symbolic Character of Consumer Goods and Activities. Bloomington: Indiana University press. 
McCreery, John 1995 Malinowski, 'Magic, and Advertising: On choosing Metaphors.' in J.F. Sherry, Jr. (Ed.) Contemporary Marketing and Consumer Behavior. Thousand Oaks, CA: Sage Publications. 309-329.

McLuhan, Marshall 1967 [1951] The Mechanical Bride: Folklore of Industrial Man, $2^{\text {nd }} \mathrm{Ed}$, Boston: Beacon.

Miller, Daniel 1997 Capitalism: An Ethnographic Approach. Oxford, UK: Berg.

Moeran, Brian 1996a A Japanese Advertising Agency. Honolulu: University of Hawaii Press.

Moeran, Brian 1996b 'The Orient strikes back: advertising and imagining Japan.' Theory, Culture \& Society 13 (3): 77-112.

Moeran, Brian 2003 'Celebrities and the Name Economy.' in N.

Dannhaeuser and C. Werner (Eds), Anthropological Perspectives on Economic Development and Integration. Amsterdam: Elsevier. Vol. 22: 299-321.

Moeran, Brian 2006 Ethnography at Work. Oxford: Berg.

Moeran, Brian 2009 'The organization of creativity in Japanese advertising production,' Special Issue: 'Managing in the creative industries: Managing the motley crew,' Human Relations 62 (7): 963985.

Morais, Robert J. 2007 'Conflict and Confluence in Advertising Meetings,' Human Organization, 66(2): 150-159.

O'Barr, William 1994 Culture and the Ad. Boulder, CO: Westview Press.

Ogilvy, David 1963 Confessions of an Advertising man. New York: Antheneum.

Ogilvy, David 1985 [1983] Ogilvy on Advertising. New York: Vintage books.

Packard, Vance 1957 The Hidden Persuaders. New York: David McKay Co.

Perry, Nick 1998 Hyperreality and Global Culture. London: Routledge.

Reeves, Rossier 1961 Reality in Advertising. New York: Knopf.

Rothenberg, Randall 1994 Where the Suckers Moon: An Advertising Story. New York: Knopf.

Sacks, Danielle 2010 'The Future of Advertising.' in Fast Company. http://www.fastcompany.com/magazine/151/mayhem-on-madisonavenue.html. 17, November.

Schudson, Michael 1984 Advertising, The Uneasy Persuasion. New York: Basic Books. 
Sherry, John 1987 'Advertising as a Cultural System.' In J. UmikerSebeok (ed.) Marketing and Semiotics: New Directions in the Study of Signs for Sale, pp. 441-62. Berlin and New York: Mouton de Gruyter.

Sunderland, Patricia L. and Denny, Rita M. 2007 Doing Anthropology in Consumer Research. Walnut Creek, CA: Left Coast Press.

Tanaka, Keiko 1994 Advertising Language. London: Routledge.

Turner, Ernest S. 1953 The Shocking History of Advertising. New York: Ballantine Books.

Twitchell, James 1996a 'But First a Word From our Sponsor.' The Wilson Quarterly, pp. 67-77.

Twitchell, James 1996b AdCult USA: The Triumph of Advertising in American Culture. New York: Columbia University Press.

Van Maanen, John 1988 Tales of the Field: On Writing Ethnography. Chicago: University of Chicago Press.

Vestergaard, Torbin and Schroder, Kim 1985 The Language of Advertising. Oxford: Basil Blackwell.

Williamson, Judith 1978 Decoding Advertising. London: Marion Boyars.

Young, James W. 1946 The Diary of an Ad Man. Original from the University of Virginia, Charlottesville: Advertising Publications.

Young, James W. [1963] 2001 How to Become an Advertising Man. New York: McGraw-Hill. 
Timothy de Waal Malefyt is Visiting Associate Professor of Marketing at Fordham University Business School in NYC. Dr. Malefyt previously led an in-agency culture-insight group at BBDO advertising in NYC, and worked on Cadillac's revival as Account Planner at D'Arcy, Masius, Benton and Bowles in Detroit. He is co-author of Advertising and Anthropology and co-editor of Advertising Cultures. He is frequently cited in Business Week, the NYTimes, and USA TODAY. He may be reached at timothy.malefyt@gmail.com. 